\title{
Optical and luminescence properties of Er,Yb:YAG crystals grown by horizontal directional crystallization method
}

\author{
S.V.Nizhankovskyi, A.A.Kozlovskyi, N.O.Kovalenko, O.O.Vovk \\ Institute for Single Crystals, STC "Institute for Single Crystals", National \\ Academy of Sciences of Ukraine, 60 Nauky Ave., 61001 Kharkiv, Ukraine
}

Received July 12, 2018

\begin{abstract}
The spectral properties of $\mathrm{Er}, \mathrm{Yb}$ co-doped $\mathrm{Y}_{3} \mathrm{Al}_{5} \mathrm{O}_{12}$ single-crystals grown for the first time by modified horizontal directional crystallization method in reducing atmosphere $\mathrm{Ar}+\left(\mathrm{CO}, \mathrm{H}_{2}\right)$ are reported in the paper. Optical absorption and photoluminescence spectra indicated that doping ions are effectively incorporated into the garnet crystal matrix. Photoluminescence spectra were measured under the $920 \mathrm{~nm}$ excitation. The strongest IR emission peaks were located at $1531 \mathrm{~nm}$ and $1619 \mathrm{~nm}$. The up-conversion red and green emission lines were also recorded.

Keywords: $E r, Y b: Y A G$, modified horizontal directional crystallization method, reducing atmosphere, optical absorption, photoluminescence, energy transfer, up-conversion.

Представлены результаты измерений спектральных свойств солегированных $\mathrm{Er}$ и $\mathrm{Yb}$ монокристаллов $\mathrm{Y}_{3} \mathrm{Al}_{5} \mathrm{O}_{12}$, впервые выращенных методом модифицированной горизонтальной направленной кристаллизации в восстановительной атмосфере $\mathrm{Ar}+\left(\mathrm{CO}, \mathrm{H}_{2}\right)$. Спектральные исследования оптического поглощения и фотолюминесценции показали, что ионы легирующих примесей входят в кристаллическую матрицу граната. Спектры фотолюминесценции измерялись при возбуждении 920 нм. Наиболее интенсивными были пики ИК-излучения 1531 нм и 1619 нм. Также зарегистрированы линии ап-конверсионного красного и зеленого излучения.
\end{abstract}

Оптичні і люмінесцентні властивості кристалів Er,Yb:YAG, вирощених методом горизонтальної спрямованої кристалізації. С.В.Ніжанковський, А.А.Козловський, Н.О.Коваленко, О.О.Вовк.

Наведено результати вимірювань спектральних властивостей співлегованих $\mathrm{Er}$ та $\mathrm{Yb}$ монокристалів $\mathrm{Y}_{3} \mathrm{Al}_{5} \mathrm{O}_{12}$, вперше вирощених методом модифікованої горизонтальної спрямованої кристалізації у відновній атмосфері $\mathrm{Ar}+\left(\mathrm{CO}, \mathrm{H}_{2}\right)$. Спектральні дослідження оптичного поглинання і фотолюмінесценції показали, що іони легуючих домішок входять у кристалічну матрицю гранату. Спектри фотолюмінесценції вимірювалися при збудженні 920 нм. Найбільш інтенсивними були піки ІЧ-випромінювання 1531 нм та 1619 нм. Також зареєстровані лінії ап-конверсійного червоного і зеленого випромінювання.

\section{Introduction}

Lasers operating in the eye safe wavelength range near $1.5 \mu \mathrm{m}$ are widely used in many fields of technology, such as communications, ranging, air navigation etc. The lasing around $1.5 \mu \mathrm{m}$ is traditionally achieved with use of the ${ }^{4} I_{13 / 2} \rightarrow{ }^{4} I_{15 / 2}$ transition of trivalent erbium ion [1]. One of the main problems of erbium laser active media is the low optical absorption of the excited energy level ${ }^{4} I_{11 / 2}$ around $980 \mathrm{~nm}$, which reduces pump efficiency [2]. The most obvious way to enhance efficiency is to increase the concentration of erbium ions. However, due to the complex energy struc- 
ture of $\mathrm{Er}^{3+}$ and the existence of numerous energy levels that are on the energy scale above the level of ${ }^{4} I_{13 / 2}$, at increased concentrations of $\mathrm{Er}^{3+}$ ions (already more than 1-2 at. \%) co-operative processes are initiated [3] that results in a decrease in luminescence intensity (so-called concentration quenching of luminescence). This drawback is resolved by the co-activation of laser media by $\mathrm{Yb}^{3+}$ ions [4-6]. Ytterbium ions intensively absorb the excitation radiation in the region of $1 \mu \mathrm{m}$ and energy transfer $\mathrm{Yb}^{3+} \rightarrow \mathrm{Er}^{3+}$ is quite effective.

For a long time glasses of various chemical nature most often used as laser hosts for erbium activation and ytterbium sensitization [7-11]. Laser materials based on erbium-ytterbium-doped glasses have certain advantages, primarily due to the simplicity and lower cost of manufacture. Due to this, they found some application in the creation of devices for generation in the eye safe spectral range. Nevertheless they own a number of serious limitations with respect to their low damage threshold, mechanical frailness, complexity of machining and low thermal conductivity. These properties seriously limit the performance of glass based lasers particularly in average and high power applications. Therefore production of crystalline Er-activated and Yb-sensitizated materials is highly desirable.

Yttrium aluminum garnet $\mathrm{Y}_{3} \mathrm{Al}_{5} \mathrm{O}_{12}$ (YAG) single crystal is used extensively as laser active medium doped with rare-earth ions. Having a garnet structure, YAG has a number of advantages as a host matrix for laser applications including the ability to incorporate a wide range of rare-earth ions, thermal resistance, chemical inertness, mechanical strength and high thermal conductivity (the thermal conductivity of crystalline YAG is about 15 times higher than that of glass). Earlier the Er,Yb:YAG crystals were grown by the Czochralski method in an oxidizing atmosphere using iridium crucibles $[12,13]$.

The aim of the present work is investigation of optical and luminescence properties of $E r, Y b: Y A G$ single-crystals grown for the first time by modified horizontal directional crystallization (MHDC) method [14] in reducing carbon-containing environment with using molybdenum crucible.

\section{Experimental}

The crystals $\mathrm{Er}^{3+}, \mathrm{Yb}^{3+}$ :YAG $(0.5$ at. $\%$ $\mathrm{Er}^{3+}, 8$ at. $\%\left(\mathrm{Yb}^{3+}\right)$ were obtained by MHDC. Unlike the conventional horizontal

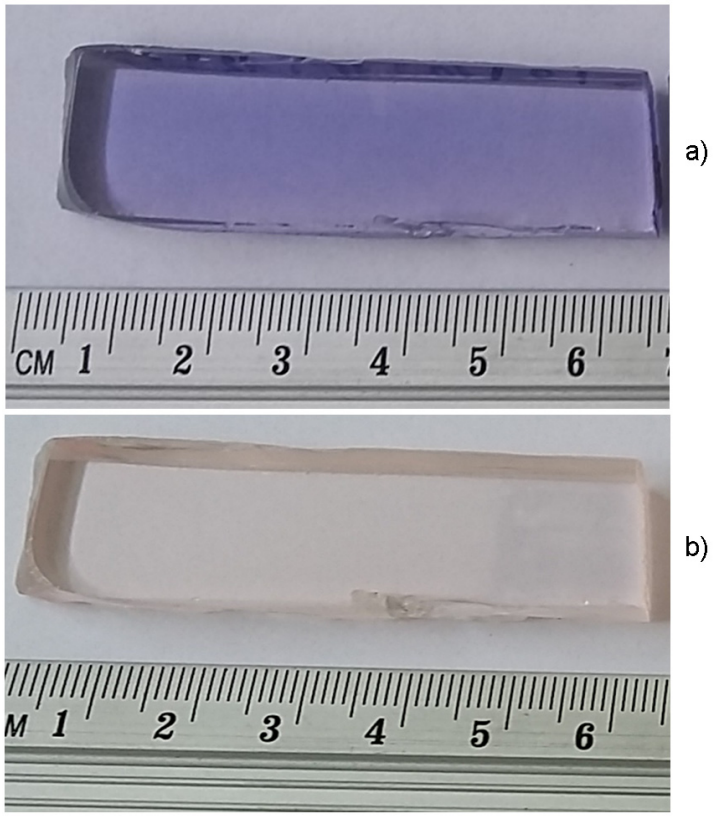

Fig. 1. Appearance of Er,Yb:YAG crystals: a) as grown, b) annealed in air.

directional crystallization in vacuum, the crystallization process were carried out in weakly reducing atmosphere $\mathrm{Ar}+\left(\mathrm{CO}, \mathrm{H}_{2}\right)$ at $0.1 \mathrm{MPa}$ pressure. Crystal dimensions were $70 \times 150 \times 15 \mathrm{~mm}^{3}$. The crystallization rate was $2-2.5 \mathrm{~mm} / \mathrm{h}$. The temperature gradient at the crystallization front was $10-30 \mathrm{~K} / \mathrm{cm}$ depending on the stage of growth and the degree of overheating of the melt. To explore the influence of the growing conditions on the optical properties, the crystals were annealed in air atmosphere.

The optical absorption spectra of the crystals were recorded at room temperature by means of a UV-Vis spectrometer (Optizen 3220 , double beam) with $1 \mathrm{~nm}$ step. The photoluminescence spectra were obtained under optical excitation by a laser diode with a emission wavelength $\lambda=920 \mathrm{~nm}$ and half-width of excitation band $\Delta \lambda=3 \mathrm{~nm}$. The photoluminescence emission detected by a $\mathrm{Ge}$ photodiode in the photo-emf mode.

\section{Results and discussion}

Fig. 1a shows a photograph of the asgrown crystal $\mathrm{Er}^{3+}, \mathrm{Yb}^{3+}: \mathrm{YAG}$, which had a blue-violet color. The annealing in an oxidizing atmosphere eliminates coloration of crystal (Fig. 1b).

The optical absorption spectra of the grown crystal are presented in Fig. 2. The sharp absorption lines in the spectral region $400 \mathrm{~nm}<\lambda<900 \mathrm{~nm}$ are attributed to the transitions of the $\mathrm{Er}^{3+}$ ions from the ground 


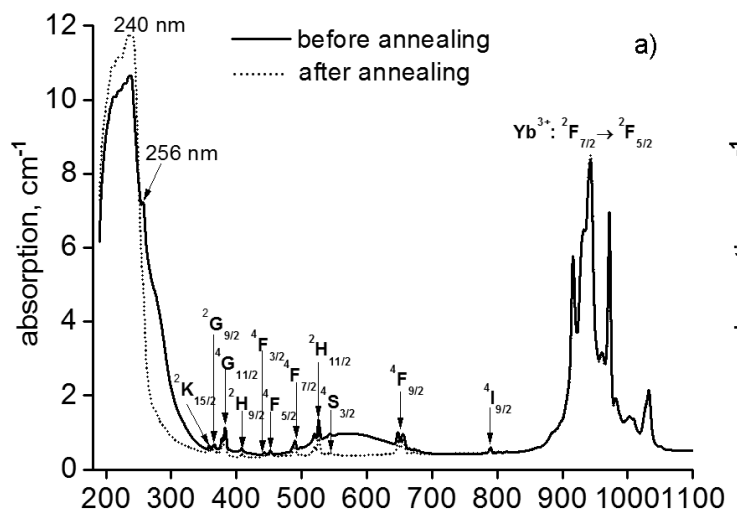

$\lambda, \mathrm{nm}$

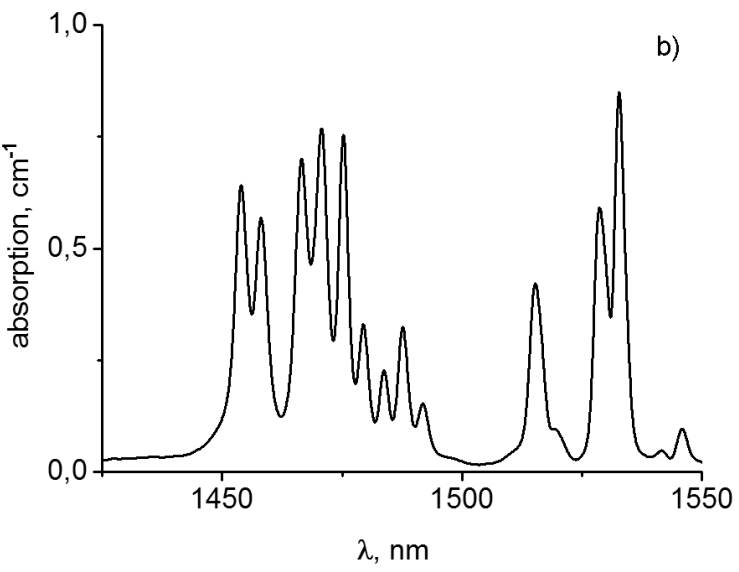

b)

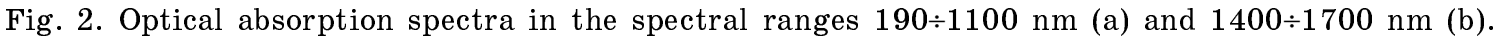

state ${ }^{4} I_{15 / 2}$ to the different excited energy levels [15-17]. These peaks marked in the Fig. 2,a completely coincide with the absorption lines of erbium ions in $\mathrm{Er}^{3+}$ :YAG single crystals grown by the HDC method [18]. In the spectral range of $0.9-1 \mu \mathrm{m}$ several broad absorption bands were recorded. Three of which, the most intense (at $916 \mathrm{~nm}, 944 \mathrm{~nm}, 972 \mathrm{~nm}$ ), coincide with the bands of absorption of $\mathrm{Yb}^{3+}$ ions in $\mathrm{Yb}^{3+}$ :YAG (5 at. $\% \mathrm{Yb}^{3+}$ ) [19]. The bands at $916 \mathrm{~nm}$ and $944 \mathrm{~nm}$ correspond to the optical transitions between Stark components of the ground-state multiplet manifold, ${ }^{2} F_{7 / 2}$ and the excited state ${ }^{2} F_{5 / 2}$ of $\mathrm{Yb}^{3+}$ ions. The intense band at $972 \mathrm{~nm}$ is mainly attributed to the strong ${ }^{2} F_{7 / 2} \rightarrow{ }^{2} F_{5 / 2}$ transition of the $\mathrm{Yb}^{3+}$ ions. However, the much weaker ${ }^{4} I_{15 / 2} \rightarrow{ }^{4} I_{11 / 2}$ transition of $\mathrm{Er}^{3+}$ ions [18] also contributes to formation of this band. The main ytterbium absorption lines are much wider than erbium absorption lines. This is due to the vibronic nature .of the energy transitions of ytterbium [20]. The appearance of additional sideband at a wavelength of $932 \mathrm{~nm}$ is also attributed to vibronic character of these transitions.

In addition to absorption lines of activators, the broad absorption band 550$600 \mathrm{~nm}$ and the intensive UV absorption maxima are observed. The annealing eliminates absorption band at 550-600 $\mathrm{nm}$. The appearance of this band in unannealed crystal, as in the crystals of $\mathrm{Er}^{3+}$ :YAG, grown by HDCM method in reducing atmosphere [18], is due to a small amount of impurity $\mathrm{Ti}^{3+}$ $\left(\approx 10^{-3}\right.$ wt. $\left.\%\right)$. The oxidizing annealing changes the charge state of titanium ions $\mathrm{Ti}^{3+} \rightarrow \mathrm{Ti}^{4+}$. The absorption band of of $\mathrm{Ti}^{4+}$ ions is in the UV region of $220-225 \mathrm{~nm}$. This explains the decoloration of the crystal after annealing. The intensive absorption maxima in UV spectrum region were recorded at $240 \mathrm{~nm}$ and $256 \mathrm{~nm}$. Annealing in an oxidizing atmosphere eliminates the absorption band at $256 \mathrm{~nm}$, which indicates its connection with the $F$-centers. The appearance of absorption band near $240 \mathrm{~nm}$ in undoped YAG crystals grown in a reducing atmosphere and in carbon doped YAG has been reported in a number of works [21-23]. This band was attributed to oxygen vacancies. The absence of a decrease in the optical absorption at $240 \mathrm{~nm}$ after annealing in an oxidizing atmosphere indicates another origin of this band not associated with $F$-centers in $\mathrm{Er}^{3+}, \mathrm{Yb}^{3+}: \mathrm{YAG}$ crystals grown by HDCM method in reducing atmosphere.

It should be noted that the ${ }^{4} G_{11 / 2}$ and ${ }^{2} H_{11 / 2}$ transitions observed in the visible spectral region are so-called hypersensitive optical transitions, whose intensities are extremely sensitive to the least changes in the coordination sphere of rare earth ions [24].

Deducing from the absence of differences in the intensities and positions of these transitions for grown $\mathrm{Er}^{3+}, \mathrm{Yb}^{3+}: \mathrm{YAG}$ crystals and $\mathrm{Er}^{3+}: \mathrm{YAG}$ crystals also obtained by HDCM method [18], we can conclude that the ytterbium co-doping of the YAG crystal matrix doped with erbium does not lead to changes in the symmetry of local crystalline fields. Thus, the presence of ytterbium in a fairly significant concentration does not affect the YAG matrix and its characteristics. The interaction between donor and acceptor subsystems of matrix is limited to energy transfer ${ }^{4} F_{5 / 2}\left(\mathrm{Yb}^{3+}\right) \rightarrow{ }^{4} I_{11 / 2}\left(\mathrm{Er}^{3+}\right)$.

Fig. 2,b displays the absorption spectrum of the grown crystal in the spectral region corresponding to optical transition from the ground state ${ }^{4} I_{15 / 2}$ of $\mathrm{Er}^{3+}$ ion to the its 

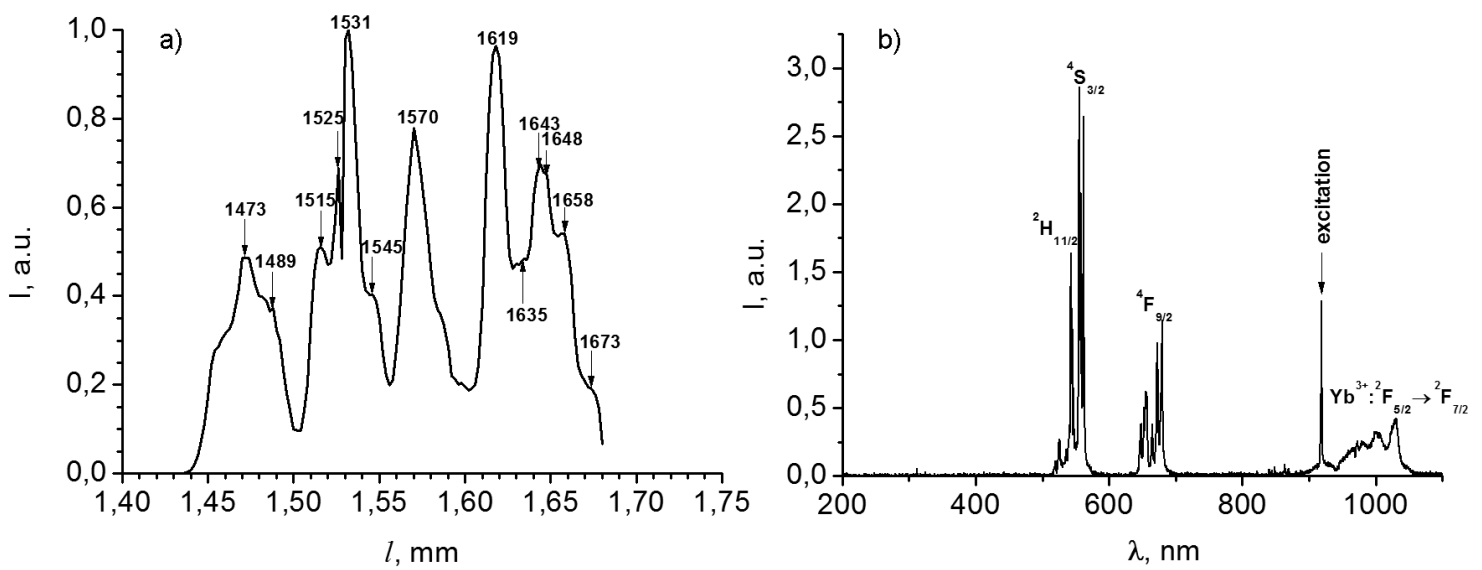

Fig. 3. Photoluminescence spectrum in: (a) the region of transition ${ }^{4} I_{13 / 2} \rightarrow{ }^{4} I_{15 / 2}$ (the numbers indicate the wavelength of the corresponding peaks in $\mathrm{nm}$ ), (b) the range 200-1100 $\mathrm{nm}$.

energy level ${ }^{4} I_{13 / 2}$ where lasing occurs. The optical absorption spectrum in this range consists of two groups of lines located below and above $1.5 \mu \mathrm{m}$ and separated by a spectral interval in the width of about $25 \mathrm{~nm}$. This feature of the absorption spectrum, which is also characteristic of $\mathrm{Er}^{3+}: \mathrm{YAG}$ crystals grown by HDCM [18], is due to splitting of the ${ }^{4} I_{15 / 2}$ and ${ }^{4} I_{13 / 2}$ multiplets of the $\mathrm{Er}^{3+}$ into several Stark components, which form two groups of closely spaced energy levels separated by a wider energy interval $[15,25]$.

The photoluminescence spectra in the range of 1400-1700 nm and 200-1100 nm are presented in Fig. 3, a and Fig. 3,b, respectively. For optical excitation, the radiation of a laser diode with a wavelength $\lambda=$ $920 \mathrm{~nm}$ was used. The photoluminescence spectrum of the optical transition ${ }^{4} I_{13 / 2} \rightarrow{ }^{4} I_{15 / 2}$ of $\mathrm{Er}^{3+}$ ions consists of two groups of lines separated in a region near $1600 \mathrm{~nm}$ by interval of about $25 \mathrm{~nm}$ (Fig. 3 ,a). The lines have a rather large halfwidth (approximately $15 \mathrm{~nm}$ ), which makes them merge into fairly broad bands. This is in contrast with both the absorption lines of $\mathrm{Er}^{3+}, \mathrm{Yb}^{3+}: Y A G$ crystal (see Fig. 2,b) and the emission lines of the Er:YAG crystal grown by HDCM method [18] in this spectral range being significantly narrow (about $1 \mathrm{~nm}$ ). This difference can be explained by the fact that the excitation of $\mathrm{Er}^{3+}$ ions in the $\mathrm{Er}^{3+}, \mathrm{Yb}^{3+}: \mathrm{YAG}$ crystal is due to the energy transfer from the $\mathrm{Yb}^{3+}$ ions, whose energy transitions are vibronic and characterized by wide spectral bands. The luminescence peaks at $1531 \mathrm{~nm}$ and $1619 \mathrm{~nm}$ are the most intensive.
The intense up-conversion photoluminescence bands were observed in visible spectral region, as shown in Fig. 3,b. The recorded green emission lines at around 525 and $555 \mathrm{~nm}$ are assigned to the Stark components of the ${ }^{2} H_{11 / 2} \rightarrow{ }^{4} I_{15 / 2}$, and ${ }^{4} S_{3 / 2} \rightarrow{ }^{4} I_{15 / 2}$ transitions, respectively. The photoluminescence lines corresponding red region of spectrum $(660-680 \mathrm{~nm})$ are assigned to the ${ }^{4} F_{9 / 2} \rightarrow{ }^{4} F_{15 / 2}$ transition.

Fig. 4 shows the energy levels diagram of crystal YAG co-doped with $\mathrm{Er}^{3+}$ and $\mathrm{Yb}^{3+}$ ions and the possible up-conversion mechanisms excited with $920 \mathrm{~nm}$ emission. Based on the energy diagram the main mechanism of up-conversion process is energy transfer (ET) from the $\mathrm{Yb}^{3+}$ ion (sensitizer) to the $\mathrm{Er}^{3+}$ ion (activator). The $\mathrm{Yb}^{3+}$ ion absorbs a photon with $\lambda=920 \mathrm{~nm}$ upon an irradiation and transits from the ground state ${ }^{4} F_{7 / 2}$ to the excited state ${ }^{4} F_{5 / 2}$. Since the energies of sensitizer excited state ${ }^{4} F_{5 / 2}$ and activator excited state ${ }^{4} I_{11 / 2}$ are nearly equal and the energy states of the $\mathrm{Er}^{3+}$ ion have a long lifetime, sensitizer can non-radiatively transfer energy to activator, which transits from the ground level ${ }^{4} I_{15 / 2}$ to the excited level ${ }^{4} I_{11 / 2}$.

When a second energy transfer from another excited $\mathrm{Yb}^{3+}$ ion occurs, the $\mathrm{Er}^{3+}$ ion is excited to its ${ }^{4} F_{7 / 2}$ state, at energy of Stark components being twice the ${ }^{4} I_{11 / 2}$ state energy. The populated ${ }^{4} F_{7 / 2}$ state of erbium relaxes through non-radiation transitions to lower ${ }^{2} H_{11 / 2},{ }^{4} S_{3 / 2}$ and ${ }^{4} F_{9 / 2}$ levels and ion then returns to its ground state, emitting photons in the green and red parts of the spectrum.

It is known that the up-conversion luminescence intensity $I_{u p}$ depends on the exci- 


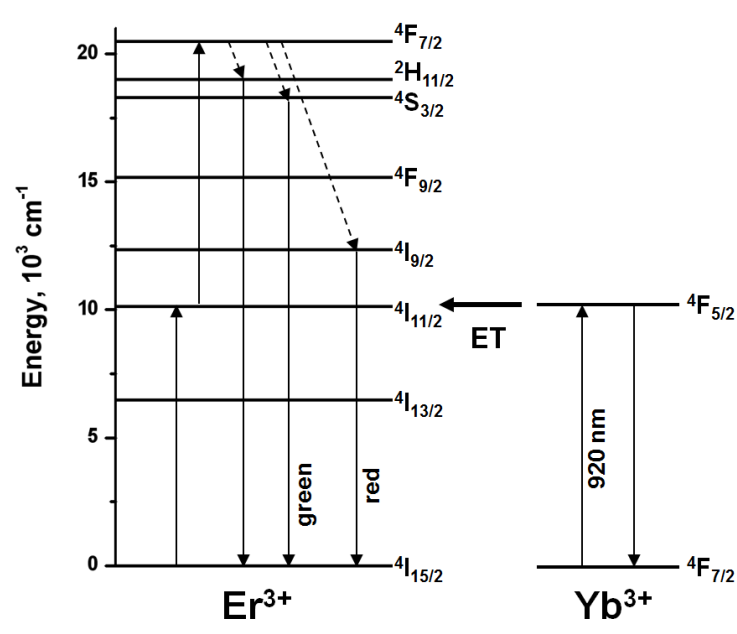

Fig. 4. Diagram of the energy levels and the mechanisms of upconversion for $\mathrm{Er}^{3+} / \mathrm{Yb}^{3+} \mathrm{co}-$ doped YAG crystal.

tation intensity $I$ according to the relation $I_{u p} \sim I^{n}$ where $n$ is the number of photons involved in the up-conversion process [26]. Thus, in order to ascertain the important information about the number of energy transfers ${ }^{4} F_{7 / 2}\left(\mathrm{Yb}^{3+}\right) \rightarrow{ }^{4} I_{11 / 2}\left(\mathrm{Er}^{3+}\right)$ in the each up-conversion step, the green and red emission intensities were measured as a function of excitation intensity.

Fig. 5 shows dependence of up-conversion emission intensity on excitation intensity for the luminescence lines corresponding to optical transitions ${ }^{4} S_{3 / 2} \rightarrow{ }^{4} I_{15 / 2}$ $(555 \mathrm{~nm}, 562 \mathrm{~nm})$ and ${ }^{4} F_{9 / 2} \rightarrow{ }^{4} I_{15 / 2}$ $(672 \mathrm{~nm}, 680 \mathrm{~nm})$. The logarithmic plots of $I_{u p}(I)$ are straight lines with slope $n$. The obtained slope value is $\sim 1.7$ for all investigated dependences. Thus, the relationship between the luminescence intensity and the excitation intensity is close to quadratic dependence. This indicates that two-photon energy transfer ${ }^{4} F_{7 / 2}\left(\mathrm{Yb}^{3+}\right) \rightarrow{ }^{4} I_{11 / 2}\left(\mathrm{Er}^{3+}\right)$ is the main up-conversion mechanism for $\mathrm{Er}^{3+} / \mathrm{Yb}^{3+}$ co-doped YAG crystal host under $920 \mathrm{~nm}$ excitation. To reduce the energy losses associated with up-conversion due to two-photon energy transfer between the activator and the sensitizer, it is necessary to optimize the ratio of their concentrations for lasing applications.

\section{Conclusions}

0.5 at $\% \mathrm{Er}^{3+}, 8$ at. $\% \mathrm{Yb}^{3+}$-co-doped YAG single-crystals have been grown for the first time by modified horizontal directional crystallization method in reducing atmosphere $\mathrm{Ar}+\left(\mathrm{CO}, \mathrm{H}_{2}\right)$. The optical spectroscopic measurements have indicated that the main

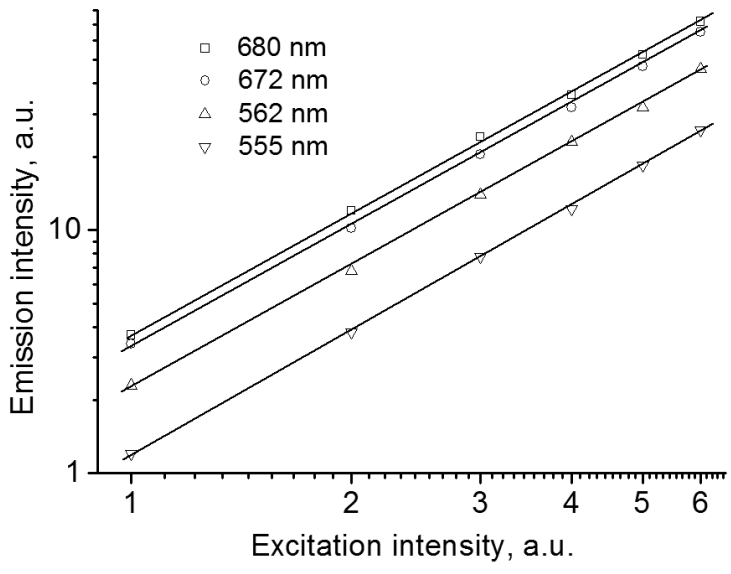

Fig. 5. Dependences of up-conversion emission on excitation intensity for

spectral lines correspond to optical transitions between the ground and excited states of doping ions incorporated into the YAG crystal lattice. In absorption spectra there were present the bands in UV region attributed to $F$-centers, which reduced or disappeared completely after annealing in oxidizing atmosphere. The infrared photoluminescence spectra presented several emission peaks in the 1450-1700 $\mathrm{nm}$ ranges, which is due to the transition ${ }^{4} I_{13 / 2} \rightarrow{ }^{4} I_{15 / 2}$. These emission bands in the $\mathrm{Er}^{3+}, \mathrm{Yb}^{3+}: \mathrm{YAG}^{3}$ single-crystals are much wider than in the Er:YAG single-crystals also grown MHDC, which indicates an effective energy transfer from $\mathrm{Yb}^{3+}$ to $\mathrm{Er}^{3+}$. Up-conversion photoluminescence was detected in visible spectral range. Analysis of the photoluminescence spectra showed that visible up-conversion luminescence occurs as a result of two-photon absorption.

\section{References}

1. A.H.Kevshyn, V.V.Halyan, T.A.Semenyuk, Phys.Chem. Solid State, 16, 245 (2015).

2. J.Hostasa, L.Esposito, A.Malchere, J.Mater. Res., 29, 2288, (2014).

3. V.I.Zhekov, T.M.Murina, A.M.Prokhorov et al., Quant. Electron., 13, 419 (1986).

4. Koechner, M.Bass, Solid-State Lasers, Springer-Verlag, New York (2003).

5. R.C.Stoneman, Solid-State Lasers and Applications, CRC Press Taylor \& Francis Group, Boca Raton, London, New York (2007).

6. Mierczyk, M.Kwasny, K.Kopczynski et al., J. Alloys and Comp., 300-301, 398 (2000).

7. E.Snitzer, R.Woodcock, Appl.Phys. Lett., 6, 45 (1965).

8. E.Georgiou, O.Musset, J.P.Boquillon, Appl. Phys. B, 70, 755 (2000). 
9. T.Danger, G.Huber, K.Petermann et al., Proc. OSA Advanced Solid State Laser Conference (ASSL) (1998), p.305.

10. P.Laporta, S.Taccheo, S.Longhi et al., Opt. Lett., 18, 1232 (1993).

11. Y.E.Sverchkov, B.I.Denker, G.V.Maximova et al., Proc. SPIE, 1627, Solid-State Lasers III (1992), p.37.

12. L.Dobrzycki, E.Bulska, D.A.Pavlak et al., Inorg. Chem., 43, 7656 (2004).

13. Z.Mierczyk, K.Kopczynski, M.Kwasny et al., Proc. SPIE, 4412, Growth, Characterization, and Applications of Single Crystals (2001), p.406.

14. S.V.Nizhankovskyi, A.V.Tan'ko, N.S.Sidelnikova et al., Cryst. Res. and Tech., 50, 223 (2015).

15. G.W.Burdick, J.B.Gruber, K.L.Nash et al., Spectrosc. Lett., 43, 406 (2010).

16. D.K.Sardar, C.C.Russell III, J.B.Gruber et al., J.Appl.Phys., 97, 123501 (2005).

17. J.B.Gruber, A.S.Nijjar, D.K.Sardar et al., $J$. Appl.Phys., 97, 063519 (2005).
18. S.V.Nizhankovskyi, A.A.Kozlovskyi, N.O.Kovalenko et al., Functional Materials, 25, 646 (2018).

19. B.Denker, B.Galagan, V.Osiko et al., Opt. Commun., 271, 142 (2007).

20. V.V.Ovsyankin, Spectroscopy of Solids Containing Rare Earth Ions, ed. by A.A.Kaplyanskii, R.M.Macfarlane, Elsevier Science Publishers B.V., The Netherlands (1987), p.343.

21. Xin-Bo Yang, Jun Xu, Hong-Jun Li et al., J. Appl. Phys., 106, 033105 (2009)

22. M.Springis, A.Pujats, J.Valbis, Phys. Condens. Matter., 3, 5457 (1991).

23. N.Shiran, A.Gektin, K.Hubenko, Functional Materials, 23, 191 (2016).

24. C.K.Jorgensen, B.R.Judd, Mol.Phys., 8, 281 (1964).

25. Kh.S.Bagdasarov, V.I.Zhekov, V.A.Lobachev et al., Yttrium-erbium-aluminum Garnet Laser, Nauka, Moscow (1989) [in Russian].

26. F.Auzel, Chem. Rev., 104, 139 (2004). 